\title{
Ewolucja zadośćuczynienia za śmierć osoby bliskiej od Kodeksu zobowiązań do Kodeksu cywilnego
}

\section{Uwagi wstępne}

Tnstytucja zadośćuczynienia za śmierć osoby bliskiej, przywrócona

1 stosunkowo niedawno do kodeksu cywilnego ustawą z 30 maja 2008 r. o zmianie ustawy - Kodeks cywilny oraz niektórych innych ustaw (DzU, nr 116, poz. 731, dalej jako: „ustawa z 2008 r.”) i uregulowana obecnie w art. $446 \S 4$ k.c. stanowi doskonałą ilustrację dwóch zjawisk, które dla historyka prawa nie stanowią niespodzianki, praktykom jednak warto je przypomnieć. Po pierwsze, na przykładzie historii rozwoju tej instytucji widać jaskrawo, jak na rozwój prawa cywilnego nawet $\mathrm{w}$ obszarach, zdawałoby się, odległych od fundamentalnych dyskusji ideologicznych czy bieżących sporów społecznych czy politycznych - mają wpływ zmiany w przyjmowanym przez społeczeństwo systemie wartości, relacjach międzyludzkich i społecznej wrażliwości. Jest też doskonałym przykładem jeszcze jednego zjawiska godnego uwagi, mianowicie kreatywnej, prawotwórczej wręcz roli judykatury w rozwoju prawa. To bowiem orzecznictwo kilkakrotnie w historii tej instytucji $\mathrm{w}$ prawie polskim diametralnie zmieniało wykładnię norm dekodowanych w przepisach, których wykładnia literalna prowadziła do wniosków przeciwnych niż te, które wynikały z judykatów. $Z$ tych przyczyn meandry będące udziałem tej instytucji na przestrzeni 83 lat, licząc ten okres od momentu wejścia w życie prawa zunifikowanego, zasługują na przypomnienie $\mathrm{w}$ ramach niniejszej księgi, poświęconej historii prawa. 


\section{Zadośćuczynienie za śmierć osoby bliskiej w prawie historycznym i porównawczym}

Przedstawienie historii orzecznictwa dotyczącego omawianej instytucji winno być poprzedzone, chociażby ramowym, zarysowaniem jej kształtu w różnych porządkach prawnych, przede wszystkim w prawie francuskim, które wywarło największy wpływ na prawo polskie w interesującym nas zakresie. Zgodnie $z$ art. 1382 k.c.f., każde zawinione wyrządzenie szkody zobowiązuje sprawcę do jej naprawienia. Na gruncie powyższego przepisu w orzecznictwie francuskim dla uwzględnienia powództwa o zadośćuczynienie za krzywdę moralną dommage moral doznaną wskutek śmierci osoby bliskiej wystarczy udowodnienie, że naruszone zostały uczucia przywiązania do zmarłego sentiments d'affection. Orzecznictwo charakteryzował szeroki krąg osób uprawnionych, niekoniecznie wywodzących się z najbliższej rodziny. Zadośćuczynienie za śmierć osoby bliskiej dla członków rodziny przewiduje także art. 47 pr. obl. szwajc.

Omawiana instytucja nie jest z kolei znana kodeksowi cywilnemu niemieckiemu (§ 844) ani austriackiemu (§ 1325 k.c. austr.) $)^{1}$, jak również judykaturze niemieckiej. Nie była też znana $w$ ustawodawstwie radzieckim, jako sprzeczna z moralnością socjalistyczną.

Co charakterystyczne, w tych porządkach prawnych, które nie przewidują zadośćuczynienia za śmierć osoby bliskiej (np. niemieckie, włoskie), w orzecznictwie szeroko ujmuje się szkodę majątkowa, obejmując nim np. rozstrój zdrowia ${ }^{2}$.

\section{Stanowisko Kodeksu zobowiązań}

Kodeks zobowiązań regulując zakres odszkodowania, podążając za rozwiązaniem romańskim i uwzględniając dorobek orzecznictwa francuskiego wyrosłego na gruncie art. 1382 k.c.f., przewidział również zadośćuczynienie za śmierć osoby bliskiej. Zgodnie z art. 166 k.z. w razie śmierci poszkodowanego wskutek uszkodzenia ciała lub wywołania rozstroju zdrowia, sąd może przyznać najbliższym członkom rodziny zmarłego

${ }^{1}$ Szerzej na temat prawa porównawczego por. A. Szpunar, Odszkodowanie na rzecz najbliższych członków rodziny zmarłego, „Państwo i Prawo” 1968, nr 11, s. 724 i n.; tenże, Odszkodowanie w razie śmierci osoby bliskiej, Warszawa 1973, s. 24 i n.; R. Longchamps de Berier, Zobowiazania, Poznań 1948, s. 299.

${ }^{2}$ A. Szpunar, Odszkodowanie na rzecz..., s. 43. 
bądź instytucji przez nich wskazanej, stosowną sumę pieniężna, jako zadośćuczynienie za doznaną przez nich krzywdę moralną.

Jak przyjmowano $\mathrm{w}$ piśmiennictwie miało ono charakter fakultatywny. Obejmowało zadośćuczynienie za krzywdę moralna, poniesioną przez śmierć osoby bliskiej i należało się najbliższym członkom rodziny zmarłego. Ocena, kto jest najbliższym członkiem rodziny pozostawiona została ostatecznie sądowi, uznawano, że nie musi to być osoba należąca do najbliższego kręgu rodzinnego ${ }^{3}$. Krzywdę moralną w piśmiennictwie rozumiano jako obejmująca zarówno cierpienia fizyczne, jak i moralne (krzywda moralna sensu stricto $)^{4}$.

Wypada w tym miejscu wspomnieć, że krzywda moralna rozumiana była $\mathrm{w}$ orzecznictwie międzywojennym szeroko. W orzeczeniu z 16 listopada 1937 r. zdefiniowano ją jako wszelką krzywdę natury psychicznej, a więc każde rzeczywiste $\mathrm{w}$ tej dziedzinie cierpienie ${ }^{5}$. W orzeczeniu z 15 stycznia 1937 r. uznano z kolei, że utrata przez rodziców nadziei na doczekanie się z dziecka, podpory starości, należy do sfery krzywdy moralnej ${ }^{6}$. Jak czytamy również $w$ tym orzeczeniu, na ustalenie wysokości zadośćuczynienia za krzywdę moralną nie mogą mieć wpływu ani pozycja socjalna, ani majątkowa uprawnionego, ani też okoliczność, iż w procesie "przyznano mu prawo ubogich". W orzeczeniu z 4 stycznia 1937 r., Sąd Najwyższy przyjął, że sąd może odmówić zadośćuczynienia za krzywdy moralne doznane przez najbliższych wskutek śmierci poszkodowanego, gdy uzna, że krzywda jest minimalna ${ }^{7}$.

Jednocześnie, również $\mathrm{w}$ okresie międzywojennym, sformułowano dwie ważne zasady, gdy chodzi o ustalenie prawa do zadośćuczynienia. Po pierwsze uznano, że jego ustalenie jest prawem sędziowskim i jako takie nie podlega kasacji. Po drugie nie przechodzi na spadkobierców najbliższego członka rodziny tej osoby, który za swego życia wytoczył powództwo o takie zadośćuczynienie ${ }^{8}$.

${ }^{3}$ R. Longchamps de Berier, Zobowiazania..., s. 299; A. Szpunar, Odszkodowanie na rzecz..., s. 724.

${ }^{4}$ W. Czachórski, Prawo zobowiazań w zarysie, Warszawa 1970, s. 145.

${ }^{5}$ I C 2955/36, OSN (C) 1938, nr 9, poz. 393.

${ }^{6}$ II C 2097/36, OSN (C) 1938, nr 2, poz. 54; A. Bojko, Kodeks Zobowiazań w świetle orzecznictwa, Warszawa 1938, s. 40.

${ }^{7}$ C. II. 2012/36, R.P.E.S. 1937, s. 867; A. Bojko, Kodeks Zobowiazań..., s. 40.

${ }^{8}$ Tak orzeczenie SN z 31 V 1938 r., II C 3142 / 37, OSNC (C) 1939, nr 2, poz. 100. 


\section{Ewolucja powojennego orzecznictwa}

Klimat dla zadośćuczynienia zaczął się zmieniać po 1945 r. Pod wpływem nauki radzieckiej, która - jak była o tym wyżej mowa - negowała zasadność żądania zadośćuczynienia za śmierć osoby bliskiej, jako sprzecznego z zasadami moralności socjalistycznej, kwestionowano zasadność tej instytucji również na gruncie prawa cywilnego polskiego. W orzecznictwie zmiana stanowiska nastąpiła dopiero w 1951 r. Jak przyjął Sąd Najwyższy w uchwale składu siedmiu sędziów, mającej moc zasady prawnej, z 15 grudnia 1951 r., zasądzenie zadośćuczynienia za krzywdę moralną na rzecz członków rodziny zmarłego należy uznać za sprzeczne z zasadami współżycia społecznego w Państwie Ludowym, chyba że z krzywdą moralną łączy się szkoda materialna nie ulegająca zasądzeniu z mocy art. 162 k.z. ${ }^{9}$ W uzasadnieniu Sąd Najwyższy zawarł sformułowania, które ze względu na doniosłość dla praktyki sądowej wypada przytoczyć w całości: „Wynagrodzenie krzywdy moralnej przez środki materialne zmierzać może jedynie do pewnego zrównoważenia doznanej przez pokrzywdzonego przykrości zadowoleniem, jakiego dostarczy mu zasądzona z tytułu zadośćuczynienia kwota pieniężna. Kwota ta może stanowić źródło powstania lub powiększenia majątku pokrzywdzonego bądź też być przeznaczona na nabycie przedmiotów osobistego użytku lub wprost na zwiększenie bezpośredniej konsumpcji osoby, która doznała krzywdy moralnej. Satysfakcja z powiększenia majątku odpada w ustroju demokracji ludowej ze względów zasadniczych. Pozostaje satysfakcja ze zwiększonej konsumpcji, która w zasadzie nie budzi zastrzeżeń, gdy chodzi o wyrównanie osobistych cierpień fizycznych czy krzywdy moralnej związanej bezpośrednio z własną osobą. Poczucie socjalistycznej moralności razi natomiast myśl o możliwości wyrównywania przykrości doznanej przez śmierć drogiej osoby zwiększonymi wydatkami konsumpcyjnymi. Dlatego zasądzenie zadośćuczynienia za krzywdę moralną z art. 166 k.z. na rzecz najbliższych członków rodziny należy uznać z reguły za sprzeczne z zasadami współżycia społecznego w Państwie Ludowym [...]". Jednocześnie Sąd Najwyższy dostrzegł, że: „śmierć człowieka może wyrządzić osobom pozostałym różnego rodzaju szkody materialne, nieraz trudno uchwytne, których nie pozwalają zaspokoić stosunkowo wąskie ramy art. 162 k.z. Jeżeli szkoda taka istnieje, a zasądzenie zadośćuczynienia za krzywdę moralną jej nie przewyższa, pokrzywdzony w rzeczywistości obróci otrzymaną sumę na pokrycie szkody materialnej. $\mathrm{W}$ tym przypadku zastrzeżenia przeciwko wynagrodzeniu krzywdy moralnej odpadają..."

\footnotetext{
${ }^{9}$ C 15/51, OSN (CK) 1953, nr 1, poz. 3.
} 
Powyższy pogląd podtrzymany został $\mathrm{w}$ uchwale Izby Cywilnej z 29 stycznia 1957 r. ${ }^{10}$ Czytamy w niej, że żądanie zadośćuczynienia za krzywdę moralną na podstawie art. 166 k.z. nie może być uwzględnione, gdy krzywda ta polega wyłącznie na cierpieniu z powodu utraty osoby najbliższej, nie łączy się natomiast z pogorszeniem sytuacji życiowej uprawnionego. Uchwałę tę $\mathrm{w}$ doktrynie odczytano jako wyraz liberalizacji wcześniej zajętego stanowiska ${ }^{11}$.

Podsumowując, po pierwsze, w obu wyżej przywołanych judykatach wypowiedziano przede wszystkim stanowisko, że zasądzenie zadośćuczynienia za śmierć osoby bliskiej jako wynagrodzenie za krzywdę polegającą wyłącznie na cierpieniach moralnych nie jest uzasadnione. Ferując powyższe rozstrzygnięcie Sąd Najwyższy kierował się racjami opartymi na przyjętym systemie deontologicznym (moralność socjalistyczna), przy niezmienionym od okresu międzywojennego - co należy podkreślić - stanie prawnym.

Po drugie, powyższe ważne wypowiedzi orzecznictwa rozszerzają wąskie ramy i funkcję zadośćuczynienia. Dopuszcza się zadośćuczynienie nie tylko $\mathrm{w}$ razie szkód materialnych nie dających się zaspokoić na podstawie art. 162 k.z., lecz także $\mathrm{w}$ razie pogorszenia się sytuacji życiowej najbliższego członka rodziny zmarłego, wywołanej zgonem, co - jak była o tym wcześniej mowa - jest charakterystyczne dla ustawodawstw negujących zadośćuczynienie za szkodę moralną wynikającą ze śmierci osoby bliskiej. Uznaje się bowiem, że pogorszenie się sytuacji życiowej jest pojęciem szerszym i obejmuje nie dające się łatwo uchwycić szkody, których charakter jest bliski krzywdzie niemajątkowej. Obejmuje np. sytuacje, gdy zmarły łożył na utrzymanie członka rodziny kwoty wyższe niż był zobowiązany, ale także wstrząs psychiczny pokrzywdzonego, zmniejszający jego możliwości zarobkowe, sytuację w której śmierć dotyka matkę prowadzącą gospodarstwo domowe itp.

\section{Brak zadośćuczynienia za śmierć osoby bliskiej w Kodeksie cywilnym}

W tej sytuacji nie dziwi, że w projekcie kodeksu cywilnego z $1962 \mathrm{r}$. omawiana instytucja nie została uwzględniona. W projekcie art. $907 \S 3$ k.c. znajduje się tylko norma, uprawniająca najbliższych członków rodziny zmarłego do żądania stosownego odszkodowania, jeżeli wskutek jego

\footnotetext{
${ }^{10}$ I CO 37/56, OSNCK 1958, nr 1, poz. 2.

${ }^{11}$ W. Czachórski, Prawo zobowiazzań..., s. 147.
} 
śmierci nastąpiło znaczne pogorszenie ich sytuacji życiowej ${ }^{12}$. Przepis ten został następnie umieszczony $\mathrm{w}$ art. $446 \S 3$ k.c. Zgodnie $\mathrm{z}$ jego treścią sąd może przyznać najbliższym członkom rodziny zmarłego stosowne odszkodowanie, jeżeli wskutek jego śmierci nastąpiło znaczne pogorszenie ich sytuacji życiowej. Przepis ten przewidział jako przesłankę przyznania sumy pieniężnej znaczne pogorszenie sytuacji życiowej, wprowadzając na oznaczenie tego świadczenia termin odszkodowanie, zawężając zarazem zakres jego stosowania i podkreślając majątkowy jego charakter ${ }^{13}$.

W piśmiennictwie lat sześćdziesiątych i siedemdziesiątych ubiegłego wieku uznawano powszechnie, że wykładnia art. $446 \S 3$ k.c. wiązać się musi z ukształtowanym jeszcze na gruncie art. 166 k.z. kierunkiem orzecznictwa, gdyż przepis ten stanowi niejako jego zakończenie ${ }^{14} \mathrm{czy}$ też efekt wyciagnnięcia wniosków $\mathrm{z}$ dotychczasowej krytyki naukowej ${ }^{15}$. Uznawano, że wyżej przywołana uchwała Izby Cywilnej SN ukształtowała rozumienie art. $446 \S 3$ k.c. w taki sposób, że wprowadzenie terminu odszkodowanie miało na celu podkreślenie, iż konieczną przesłanką jego przyznania jest istnienie pewnych, bliżej niesprecyzowanych strat natury majątkowej, w praktyce jednak skutki wywołane śmiercią osoby bliskiej w sferze przeżyć czysto psychicznych i w szeroko pojętej sytuacji majątkowej są ze sobą ściśle powiązane i wzajemnie na siebie oddziałują tak, że niepodobna rozważyć odrębnie jednych od drugich ${ }^{16}$.

Wśród części doktryny upatrywano w odszkodowaniu z powyższego przepisu elementy niemajątkowe (tak W. Czachórski ${ }^{17}$, A. Ohanowicz ${ }^{18}$ i S. Garlicki ${ }^{19}$ ). Za wyłącznie majątkowym charakterem odszkodowania opowiadali się m.in. A. Szpunar ${ }^{20}$, A. Wolter ${ }^{21}$ i Z. Radwański ${ }^{22}$.

Powracając jednak na grunt orzecznictwa, którego ewolucja jest zasadniczym przedmiotem niniejszego opracowania, należy stwierdzić, że kształtuje ono praktykę stosowania art. $446 \S 3$ k.c., która znów, podobnie

${ }^{12}$ Projekt Kodeksu cywilnego, Warszawa 1962.

${ }^{13}$ Z. Masłowski, Kodeks Cywilny. Komentarz, red. Z. Resich, Warszawa 1972, s. 1119.

${ }^{14}$ S. Garlicki, Odpowiedzialność cywilna za nieszczęśliwe wypadki, Warszawa 1971, s. 472; W. Czachórski, System prawa cywilnego, t. III, Prawo zobowiazań. Część ogólna, Warszawa 1976.

${ }^{15}$ Z. Radwański, glosa do wyroku SN z 4.9.1967 r., I PR 23/67, OSPiKA, 1969, nr 1, poz. 5 .

${ }^{16}$ Z. Masłowski, Kodeks Cywilny..., s. 1118.

${ }^{17}$ W. Czachórski, Prawo zobowiązań..., s. 149.

${ }^{18}$ A. Ohanowicz, Zobowiązania - część ogólna, Warszawa-Poznań 1965, s. 104.

${ }^{19}$ S. Garlicki, Czyny niedozwolone w Kodeksie cywilnym, "Nowe Prawo” [dalej: NP] 1965, nr 12, s. 1399.

${ }^{20}$ A. Szpunar, Odszkodowanie na rzecz..., s. 724 i n.

${ }^{21}$ Glosa do orz. SN z 4.4.1966 r., NP, 1966, nr 12, s. 1613.

${ }^{22}$ Glosa do orz. SN z 4.9.1967 r., OSPiKA, 1969, nr 1, poz. 5. 
jak w latach pięćdziesiątych ubiegłego wieku na gruncie art. 166 k.z. nie odpowiada, czy też ściślej - nie w pełni odpowiada literalnemu brzmieniu przepisu. O ile bowiem przepis ten przewiduje odszkodowanie za szkodę majątkowa, co podkreślono m.in. w uchwale (7. zasada prawna) z 26 października 1970 r. $^{23}$, o tyle w wielu orzeczeniach Sąd Najwyższy kładzie nacisk na indemnizację szkód o charakterze $\mathrm{w}$ istocie zbliżonym do niemajątkowego. W późniejszych orzeczeniach wskazywano bowiem, że art. 446 § 3 k.c. pozwala na naprawienie nie tylko szkody majątkowej, lecz także szkody $w$ istocie zawierającej cechy szkody niemajątkowej, polegającej na znacznym pogorszeniu sytuacji życiowej osoby zainteresowanej. Wskazywano wyraźnie, że śmierć małoletniego dziecka może stanowić przyczynę pogorszenia sytuacji życiowej jego rodziców, nie tylko wtedy, gdy wywołała aktualny uszczerbek majątkowy, lecz także wtedy, gdy cierpienia rodziców osłabiły aktywność życiowa, powodując utratę możliwości polepszenia warunków życia w przyszłości.

Ten nurt orzecznictwa, wskazujący na możliwość i konieczność kompensacji uszczerbku niemajątkowego po śmierci osoby bliskiej w nowszym orzecznictwie był dominujący (por. m.in. wyrok z 15 października 2002 r., II CKN 985/00, z 25 lutego 2004 r., II CK 17/03, z 22 lipca 2004 r., II CK 479/03 i z 6 lutego 2008 r., II CSK 459/07, niepublikowane). W tym kierunku na wiele lat zostanie ukształtowana praktyka orzecznicza.

\section{Przywrócenie zadośćuczynienia za śmierć osoby bliskiej do Kodeksu cywilnego}

Sytuacja diametralnie zmienia się $\mathrm{w}$ pierwszym dziesięcioleciu XXI w. W dniu 2 sierpnia 2008 r. weszła w życie ustawa z 30 maja 2008 r. ${ }^{24}$, która do polskiego porządku prawnego wprowadza ponownie instytucję zadośćuczynienia za śmierć osoby bliskiej. Zgodnie z art. $446 \S 4$ k.c., wprowadzonym art. 1 ust. 3 powyższej ustawy, sąd może także przyznać najbliższym członkom rodziny zmarłego odpowiednią sumę tytułem zadośćuczynienia pieniężnego za doznaną krzywdę. Jak skonstatowano w doktrynie, w polskim prawie cywilnym znów funkcjonuje instytucja znana uprzednio Kodeksowi zobowiązań, a wyrugowana z Kodeksu cywilnego wyłącznie ze względów ideologicznych ${ }^{25}$.

${ }^{23}$ PZP 22/70, OSNC, 1971, nr 7-8, poz. 120.

${ }^{24}$ Art. 5 ustawy.

${ }^{25}$ A. Śmieja, System prawa prywatnego, t. VI, red. A. Olejniczak, Warszawa 2009, s. 737. 


\section{Stanowisko orzecznictwa w okresie przejściowym}

Walory tej regulacji są - jak sądzę - niezaprzeczalne. Jak wynika z uzasadnienia ustawy, jej celem było zwiększenie ochrony ofiar wypadków komunikacyjnych ${ }^{26}$. W tym miejscu jednak należy stwierdzić, że ustawa wprowadzająca ją do kodeksu nie zawierała przepisów przechodnich. Pojawiło się zatem doniosłe $\mathrm{w}$ praktyce pytanie, czy owo zadośćuczynienie może być przyznane, jeśli zdarzenie będące jego źródłem, tj. śmierć osoby bliskiej, nastąpiło przed datą wejścia w życie ustawy. Wobec braku w tym okresie regulacji ustawowej możliwej podstawy do zasądzenia zadośćuczynienia upatrywano w art. 23 i 448 k.c., a zatem w przepisach regulujących ochronę dóbr osobistych ${ }^{27}$.

Na to pytanie początkowo orzecznictwo udzielało rozbieżnych odpowiedzi. W wyroku z 14 grudnia 2007 r., I ACa 1137/07, Sąd Apelacyjny w Gdańsku uznał, że spowodowanie śmierci osoby bliskiej - męża i ojca przez osobę trzecią stanowi naruszenie dobra osobistego najbliższych członków rodziny zmarłego - żony i dzieci, w postaci prawa do życia w związku małżeńskim, posiadania ojca, życia w pełnej rodzinie, w której mąż matki jest ojcem jej dzieci ${ }^{28}$. Z kolei w wyroku z 15 lipca 2010 r. Sąd Apelacyjny w Łodzi przyjąt, że sprawca czynu niedozwolonego zaistniałego przed dniem 3 sierpnia 2008 r. (wprowadzeniem do kodeksu cywilnego art. $446 \S 4$ ), w wyniku którego doszło do śmierci poszkodowanego, nie jest biernie legitymowany $\mathrm{w}$ zakresie roszczeń wynikających z naruszenia dobra osobistego najbliższych członków rodziny zmarłego. Nie ponosi więc odpowiedzialności na podstawie art. $24 \S 1 \mathrm{w}$ zW. z art. 448 k.c. za szkody niemajątkowe powstałe na skutek naruszenia dobra osobistego tych osób w postaci życia rodzinnego ${ }^{29}$. Sąd Apelacyjny, wbrew poglądom odwołującym się do twierdzenia, że - wobec braku ustawowej regulacji zadośćuczynienia za śmierć osoby bliskiej - można jej podstaw

${ }^{26}$ Druk nr 81 Sejmu RP VI Kadencji, dostępny na www.sejm.gov.pl.

${ }^{27}$ Zgodnie z art. 23 k.c., dobra osobiste człowieka, jak w szczególności zdrowie, wolność, cześć, swoboda sumienia, nazwisko lub pseudonim, wizerunek, tajemnica korespondencji, nietykalność mieszkania, twórczość naukowa, artystyczna, wynalazcza i racjonalizatorska, pozostają pod ochroną prawa cywilnego niezależnie od ochrony przewidzianej w innych przepisach. Jak z kolei stanowi art. 448 k.c., w razie naruszenia dobra osobistego sąd może przyznać temu, czyje dobro osobiste zostało naruszone, odpowiednią sumę tytułem zadośćuczynienia pieniężnego za doznaną krzywdę lub, na jego żądanie, zasądzić odpowiednią sumę pieniężną na wskazany przez niego cel społeczny, niezależnie od innych środków potrzebnych do usunięcia skutków naruszenia. Przepis art. $445 \S 3$ stosuje się.

${ }^{28}$ I ACa 1137/07, POSA w Gdańsku 2008, nr 1, poz. 50.

${ }^{29}$ I ACa 437, OSAŁ, 2010, nr 3, poz. 23. 
upatrywać w przepisach regulujących ochronę dóbr osobistych, takiej możliwości się zatem nie dopatrzył.

Prawdziwą rewolucję przyniósł jednak wyrok Sądu Najwyższego z 14 stycznia 2010 r. $^{30}$ Teza tego orzeczenia jest tak interesująca, że warto ją przytoczyć in extenso: Spowodowanie śmierci osoby bliskiej przed dniem wejścia w życie ustawy z dnia 30 maja 2008 r. o zmianie ustawy - Kodeks cywilny oraz niektórych innych ustaw (DzU, nr 116, poz. 731) mogło stanowić naruszenie dóbr osobistych najbliższych członków rodziny zmarłego i uzasadniać przyznanie im zadośćuczynienia na podstawie art. 448 k.c.

W orzeczeniu tym Sąd najwyższy uznał, że katalog dóbr osobistych do którego odwołuje się art. 23 k.c. ma charakter otwarty. Należy do nich także prawo do życia rodzinnego i utrzymania tego rodzaju więzi. Dobro to podlega naruszeniu przez śmierć osoby bliskiej, co uzasadnia przyznanie zadośćuczynienia na podstawie art. 448 k.c.

Powyższą droga która oznaczała zerwanie z dotychczasowym kilkudziesięcioletnim dorobkiem zarówno własnym, jak i doktryny podążyło dalsze orzecznictwo $\mathrm{SN}^{31}$ i sądów powszechnych, budząc zresztą zrozumiałe zastrzeżenia $\mathrm{w}$ piśmiennictwie ${ }^{32}$. Co warto podkreślić, $\mathrm{w}$ piśmiennictwie uznano, że ten nurt w judykaturze dowodzi, iż art. $446 \S 4$ k.c. nie stanowi novum w porównaniu ze środkami, którymi dysponowały osoby pośrednio poszkodowane, należące do kręgu osób najbliższych na tle dotychczasowych przepisów k.c. ${ }^{33}$

\section{Podsumowanie}

W powyższych, nader skrótowych uwagach starałem się wykazać, jak ogromną rolę $\mathrm{w}$ kształtowaniu instytucji zadośćuczynienia za śmierć osoby bliskiej odegrało orzecznictwo. Wpływ ten dotyczył nie tylko wykładni istniejących przepisów, lecz także ich stanowienia. Jak była o tym wyżej mowa, dwukrotnie, tj. na początku lat pięćdziesiątych XX w. po raz pierwszy i po 2008 r. po raz drugi orzecznictwo najwyższej instancji

${ }^{30}$ IV CSK 307/09, OSNC - ZD, 2010, nr 3, poz. 91.

${ }^{31}$ M.in. uchwała z 22 X 2010 r., III CZP 76/10, Biul. SN, 2010, nr 10, s. 11 i wyrok z 10 XI 2010 r., II CSK 248/10, OSNC - ZD, 2011, nr 2, poz. 44; wyrok z 11 V 2011 r., I CSK 621/10, Legalis, uchwała z 13 VII 2011 r., III CZP 32/11, OSN, 2012, nr 1, poz. 10.

${ }^{32}$ M.in. M. J. Naworski, Zadośćuczynienie za śmierć osoby najbliższej do której doszło na skutek zdarzenia mającego miejsce przed dniem 3 sierpnia 2008 r., MoP, 2014, nr 11, s. 561 i n.; K. Pachnik, glosa do uchw. SN z 22 X 2010 r., III CZP 76/10, MoP, 2012, nr 13, s. 721 i n.

${ }^{33}$ M. Safjan, KC Komentarz, red. K. Pietrzykowski, Warszawa 2013, s. 1311 i przywołana tam literatura. 
sądowej wpłynęło na praktykę orzeczniczą sądów powszechnych w kierunku, którego nie sposób było przewidzieć odwołując się jedynie do metod wykładni gramatycznej. Ingerencje te w obu przypadkach wynikały z przeświadczenia o braku aktualności norm prawa pozytywnego. Nie kwestionując konstytucyjnej regulacji odnoszącej się do źródeł prawa warto zatem pamiętać o niezmiernie istotnej, niekiedy wręcz prawotwórczej roli orzecznictwa w rozwoju prawa.

\section{Bibliografia}

\section{Źródła}

I ACa 1137/07, POSA w Gdańsku 2008, nr 1, poz. 50.

I ACa 437, OSAŁ, 2010, nr 3, poz. 23.

I C 2955/36, OSN (C), 1938, nr 9, poz. 393.

I CO 37/56, OSNCK, 1958, nr 1, poz. 2.

II C 2097/36, OSN (C), 1938, nr 2, poz. 54.

II C 3142/37, OSNC (C), 1939, nr 2, poz. 100.

I CSK 621/10, Legalis.

II CKN 985/00. II CK 17/03.

II CK 479/03.

II CSK 459/07.

II CSK 248/10, OSNC - ZD, 2011, nr 2, poz. 44.

III CZP 76/10, Biul. SN, 2010, nr 10.

III CZP 32/11, OSN, 2012, nr 1, poz. 10.

IV CSK 307/09, OSNC - ZD, 2010, nr 3, poz. 91.

C. II. 2012/36, R.P.E.S. 1937.

C 15/51, OSN (CK), 1953, nr 1, poz. 3.

Projekt Kodeksu cywilnego, Warszawa 1962.

PZP 22/70, OSNC, 1971, nr 7-8, poz. 120.

Ustawa z 30 maja 2008 r. o zmianie ustawy - Kodeks cywilny oraz niektórych innych ustaw (DzU, nr 116, poz. 731).

\section{Opracowania}

Bojko A., Kodeks Zobowiazań w świetle orzecznictwa, Warszawa 1938.

Czachórski W., Prawo zobowiazań w zarysie, Warszawa 1970.

Czachórski W., System prawa cywilnego, t. III, Prawo zobowiazań. Część ogólna, Warszawa 1976.

Druk nr 81 Sejmu RP VI Kadencji; www.sejm.gov.pl.

Garlicki S., Czyny niedozwolone w Kodeksie cywilnym, „Nowe Prawo” 1965, nr 12.

Garlicki S., Odpowiedzialność cywilna za nieszczęśliwe wypadki, Warszawa 1971.

Glosa do orz. SN z 4 IV 1966 r., „Nowe Prawo” 1966, nr 12.

Glosa do orz. SN z 4 IX 1967 r., OSPiKA, 1969, nr 1, poz. 5.

Longchamps de Berier R., Zobowiazania, Poznań 1948. 
Masłowski Z., Kodeks Cywilny. Komentarz, red. Z. Resich, Warszawa 1972.

Naworski M. J., Zadośćuczynienie za śmierć osoby najbliższej do której doszło na skutek zdarzenia majacego miejsce przed dniem 3 sierpnia 2008 r., „Monitor Prawniczy” 2014, nr 11.

Ohanowicz A., Zobowiązania - część ogólna, Warszawa-Poznań 1965.

Pachnik K., glosa do uchw. SN z 22 X 2010 r., III CZP 76/10, „Monitor Prawniczy” 2012, nr 13.

Radwański Z., glosa do wyroku SN z 4 IX 1967 r., I PR 23/67, OSPiKA, 1969, nr 1, poz. 5.

Safjan M., KC Komentarz, red. K. Pietrzykowski, Warszawa 2013.

Szpunar A., Odszkodowanie na rzecz najbliższych członków rodziny zmarłego, „Państwo i Prawo” 1968, nr 11.

Szpunar A., Odszkodowanie w razie śmierci osoby bliskiej, Warszawa 1973.

Śmieja A., System prawa prywatnego, t. VI, red. A. Olejniczak, Warszawa 2009. 